\title{
NONDESTRUCTIVE TECHNIQUES IN THE STUDY OF A GILDED METALLIC SWORD FROM THE ISLAMIC ART MUSEUM
}

\author{
Gharib, A..$^{*}$ Mohamed, $\mathrm{H}^{2}$ \& Abdel Ghany, N. ${ }^{3}$ \\ ${ }^{1}$ Conservation dept., Faculty of Fine Arts, Minia Univ., Minia, Egypt \\ ${ }^{2}$ The Islamic Art Museum, Port Said St., Bab EL Khalk, Cairo, Egypt \\ ${ }^{3}$ Physical Chemistry dept., National Research Center, El Buhouth St., Dokki, Cairo, Egypt \\ E-mail: abeer.ibrahim@mu.edu.eg
}

\begin{abstract}
The paper presents results obtained from investigation of a gilded sword from Islamic Art Museum in Cairo- Egypt, with multi-analytical non-destructive methods such as optical microscopy (OM), stereo microscope (SM) and X-ray fluorescence (XRF). The present article offers a discussion of swords and sabers during the early Islamic period. The paper proposes a short review on gilding techniques and materials from metal artifacts of cultural heritage. Modern analytical methods applied to the metallic sword (which has gilded copper and iron alloys) revealed a number of structures, complex and different. The iron object degraded in the surrounding environment to emphasizing the chemical and physical processes that occur according the lying environment; the iron blade of the sword has stress due to cracks and pitting corrosion. Furthermore, XRF analysis showed that the hilt of the sword coated with wear and tear gold layer or electrum (an alloy of gold and silver). These results highlighted the chemical composition of the base alloy and gilding; it offers useful information which helps in conservation, handling and storage methods to keep the unique sword.
\end{abstract}

Keywords: Gilding, Metallic alloys, Portable equipment, Degradation effects.

\section{Introduction}

Islamic swords and arms were decorated using variety of techniques as gilding, inlay, gold and silver encrusting, as well as setting with jewels and enameling. On some ceremonial items, the decoration could achieve such sumptuous and impressive effects that the final appearance of the object has more in common with an item of jewelry than weapon. Inlay brass artifacts with gold or silver seems to have become common in Islamic art from the twelfth century [1]. The deterioration of ancient metals represents the undesired effect of some Physiochemical processes, as those involved in uncontrolled evolution - corrosion - which gradually alters their shape, nature and resistance, which makes impossible their use as historical evidence of human civilization [2] as discussed in detail in this paper. This paper presents an investigation of a gilded sword from Islamic Art Museum in CairoEgypt. The analysis of the gilded sword leads to an understanding of manufacturing and processing conditions employed by ancient craftspeople. Non-destructive analyses are value of conservation. The screening of composition and macroscopic structural features offers invaluable information when determining treatment, handling and storage methods. Microstructural studies of the gilded sword also provide details of the severity and type of corrosion as 
well as possible material instabilities $[3,4]$. The gilding could theoretically have been done by any of the following methods: proper mercury or fire gilding, gluing gold foil or sheet to the surface with mercury, or organic glue, embossing the foil onto a rough surface, even just wrapping the part in question with gold foil. The various methods are described as discussed in detail $[5,6]$. The present gilded sword is a weapon with straight double edged blade of around $95 \mathrm{~cm}$, generally pointed at its tip, and can be used for both cutting and thrusting; the gilded hilt of a sword is generally symmetrical in form, fig. (1). Although swords are usually curved, earlier examples are virtually straight. The temporary registration number is (6686) according to the catalog of the Museum of Islamic Art of Cairo. The catalog mentions the sword was a gift from Mohamed Ali Pasha, the sword dated back to the Ottoman period $15^{\text {th }}-17^{\text {th }}$ century AD. The Ottomans were descendants of Turkoman peoples who had migrated west (originally from the area of present-day China) into the Iranian plateau, and then advanced further west into Anatolia as a result of the Mongol invasions of the 1200s. An earlier group of Turkish peoples had established the Seljuk dynasty that ruled Iran, Iraq, and most of Syria. The Ottoman Empire encompassed Hungary, the Balkans, Anatolia, Syria, Mesopotamia, Egypt, and much of North Africa. The Ottomans bridged three continents, Europe, Asia, and Africa. The art of the Ottomans reflects the diversity of their empire. The impact of the Sassanid arts can be seen in the metal handicrafts of the early Islamic era. The heyday of the Islamic metalwork comes together with Seljuk Turks; there appear several novelties in materials, techniques, forms, and decoration used on them, and also a wider choice of metal products available. The Seljuk has used brass poured since the middle of the $12^{\text {th }}$ century AD. The color of this alloy is lighter and brighter than bronze [7-9]. This work investigates the sword which hasn't a corrosion layer but there were corrosion inside pits in the sword's surface by using optical, stereo microscopy and portable X-ray fluorescence spectroscopy. We analyzed the surface structures and the interference area with the metallic core of the basic alloy, intending to elucidate the nature of the materials and the technology used during the manufacture of the object. These techniques determine the elemental composition of metallic sword and evaluation the deterioration of gilded layer, which will help in conservation and treatment processes of this object. Gilding technique is an important and popular method of surface decoration. Gilding can be traced to 2300 BC. In ancient Egyptian paintings that show goldsmith making gold leaf, and the sarcophagi of nobles often had gilding decorating the outside. Gilding became popular during the New Kingdom in Egypt (1570-1070 BC) [10-12]. Gold is malleable enough to be beaten and pounded down into thin foils that become even thinner gold leaves. The process of gold beating is nearly as old as the use of gold itself. Instead of using hammers, the ancient Egyptians used round stones in order to obtain the thinnest sheet of gold possible at the time. Mechanical gilding can never have been very satisfactory, but there were two ways of improving it: 1) was to apply an adhesive between the gold and the base metal, and 2) was to overlap the edges of the gold foil and then join them by burnishing. Used in one of these ways, foil gilding was durable and the technique persisted at least until the middle of the first millennium BC $[13,14]$. One obvious way was to use an adhesive and this method is still used today for the gilding of wood and stone, and for the decoration of leather book bindings. Unfortunately, the animal or vegetable glues which were probably used have long since disappeared as the result of biological decay, and in many cases the gilding has been lost at the same time, to leave only traces of gold caught in the folds and crevices of the design. Although gilding with mercury was rare in the 
first century $\mathrm{AD}$. It had become the standard method of gilding by the third or fourth centuries. Mercury was used in a very thin coating on the substrate metal as an adhesive for gold leaf [6]. The color of gold foil or leaves varies depending on the amount of silver or copper added to the gold. The alloy gold-copper was widely used for darker applications, while the gold-silver alloy is clearer and have a major property to reflect the light. The most common metallic materials employed were silver, tin and copper alloys. The main features that led gold to be the most widely used metal for gilding are its durability and malleability [15]. The present article discusses a metallurgical characterization of the gilded sword by using optical microscopy and portable $\mathrm{X}$-ray fluorescence.

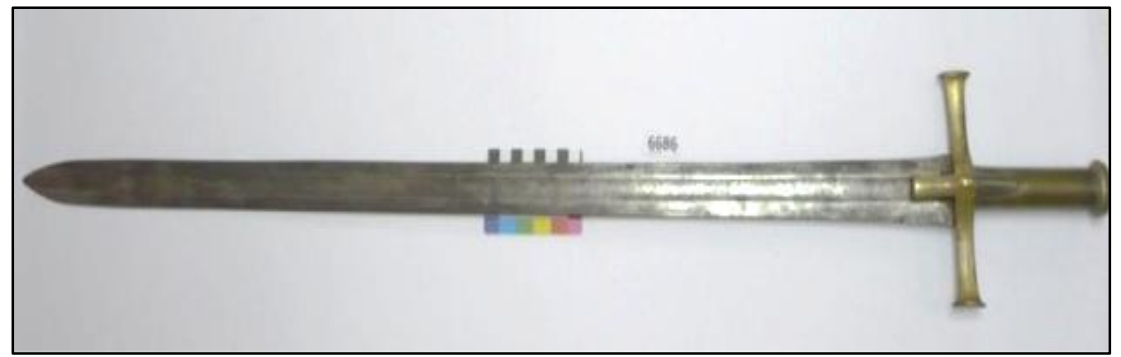

Figure (1) Shows a sword has gilded copper hilt and iron blade.

\section{Methods}

\subsection{Optical microscopy}

Optical microscopes are able to provide a wide range of information on metallurgical features and conservation state of the objects; and the metallographic approach can be considered easy to apply, a flexible research tool [16]. Microscopic observations were made on a Smart-Eye USB Digital Microscope at various magnifyications between $100 \mathrm{X}$ and $200 \mathrm{X}$, and

\subsection{X-ray fluorescence}

$\mathrm{X}$-ray fluorescence analysis was performed with portable X-Ray fluorescence NITON/XLt 8138 (USA), with software version $4.2 \mathrm{E}$, tungsten tube, $35 \mathrm{KV}, 40 \mu \mathrm{A}$, exposure time $30 \mathrm{~s}$. Portable X-Ray fluorescence consists of an X-ray tube source and a solid state diode detector at angles visible in the sampling window. X-Ray fluorescence spectrum was measured with an X-Ray beam generated by the pd target excited at $40 \mathrm{kV}$, with a tube current of $0.25 \mathrm{~mA}$ for a white X-Ray source and $1.0 \mathrm{~mA}$ for monochromatic $\mathrm{X}$-Ray. Primary X-Ray emitted from the

\section{Results}

The microscopic examination was carried out using Smart-eye USB digital microscope and stereo microscope at various magnifications to investigate the morphology and characteristics of corrosion layer the microstructures on the surface were studied under a Stereo microscope - a Zeiss (stemi 508) imaging binocular microscope (50x-200x magnification), with both visible and fluorescent lights, and an AxiocamERc 5s digital camera. Visible light observations were performed in reflection geometry.

source strike atoms with sufficient energy to eject low energy inner shell electrons, creating an unstable ion. When this occurs, an electron from a higher energy, outer orbital fills the vacancy releasing energy in the form of secondary (fluorescent) $\mathrm{X}$ Ray. The energy of any given secondary XRay is characteristic of a specific element, allowing qualitative identification of elements present in a sample. In addition, the detector also counts the number of secondary X-Ray from the sample, allowing quantitative elemental concentrations to be determined [17-19].

and the condition of the gilding layer, and to explore the technique utilized. Microscopic observation by optical microscope, fig. (2) showed that the hilt of the sword made of two separated metals the base 
metal and the gilded layer. Multi-layered microstructure consisting of very fine slime bright and dark layers is apparently visible in optical microscopy (OM) photos of each metal. The gilded layer reveals distortions, cracks and missing parts. Stereo microscope examination confirms the sword surface has many pits and pustules due to damage or corrosion processes; as showed in fig. (3). Portable X-Ray fluorescence provided us with information about the chemical composition of the sword The hilt is made from brass (alloy of copper and zinc) as a base alloy and the gilded layer or electrum (an alloy of gold and silver) consists of $\mathrm{Au}$, together with $\mathrm{Ag}$ and $\mathrm{Cu}$ and small amounts of $\mathrm{Zn}, \mathrm{Sn}$ and $\mathrm{Pb}$. Copper $(\mathrm{Cu})$ content varies from 75.5:35.62 \%, zinc $(\mathrm{Zn})$ content varies from 33.5:2.9 \%, tin (Sn) content varies from 2.19:0.83 \%, gold $\mathrm{Au})$ content varies from 25.83: 18.92 $\%$ and silver $(\mathrm{Ag})$ content varies from 28.42: $24.79 \%$ as showed in tab. (1$\mathrm{a}, \mathrm{b})$.
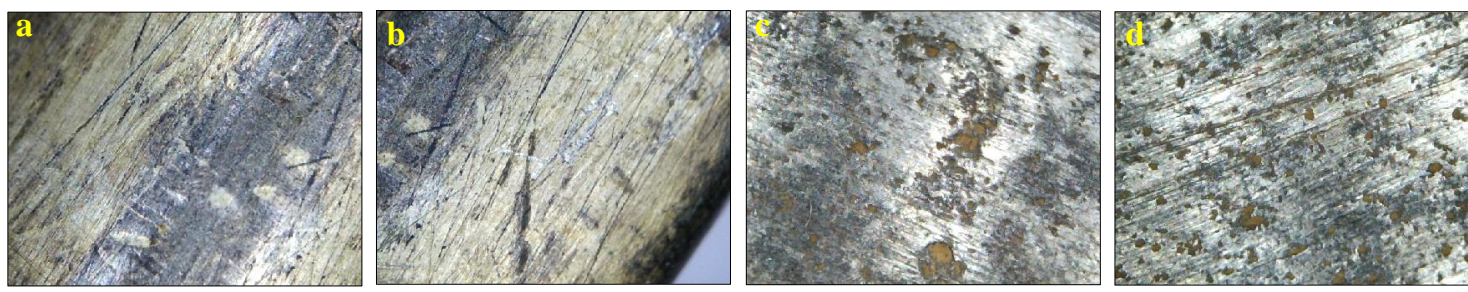

Figure (2) Shows optical observations with (100X) magnification $\underline{\mathbf{a}} \cdot \& \underline{\mathbf{b}}$. deterioration process on gilded layer (cracking and pits), ‥ \& $\underline{\mathbf{d}}$. crevice deterioration on iron blade.
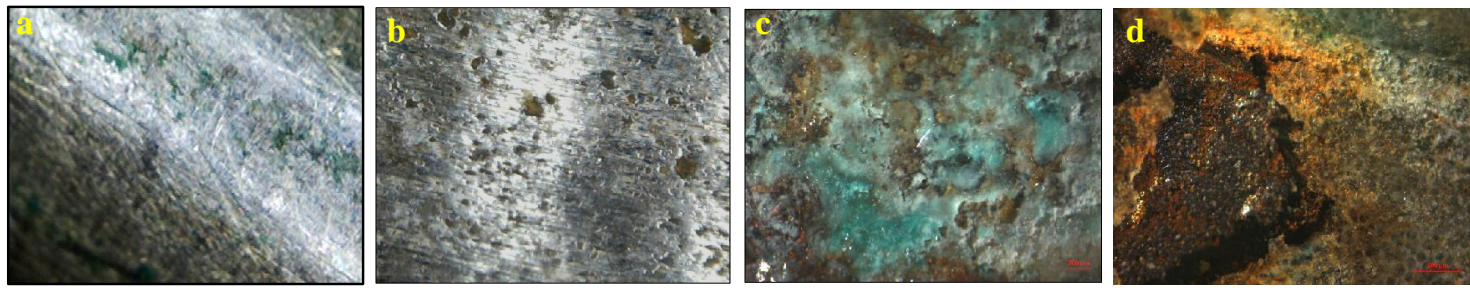

Figure (3) Shows microscopic observations by (optical and stereo microscopes) (200X) ‥ \& $\underline{\mathbf{b}}$. pits in the hilt while, $\underline{\mathbf{c}}$. \& $\underline{\mathbf{d}}$ deterioration in the iron blade.

Table (1-a) XRF elemental composition in the first face of the gilded sword.

\begin{tabular}{|c|c|c|c|c|c|c|c|c|}
\hline \multirow{2}{*}{ Sword samples } & \multicolumn{8}{|c|}{ Elements (\%) } \\
\hline & $\mathrm{Cu}$ & $Z n$ & $S n$ & $A u$ & $A g$ & $P b$ & $\mathrm{Fe}$ & $S b$ \\
\hline 1) head of the sword ${ }^{(*)}$ & 75.52 & 25.38 & 0.83 & 0 & 0.02 & 2.68 & 0.47 & 0.18 \\
\hline 2) the side of the sword head ${ }^{(*)}$ & 56.10 & 24.56 & 1.56 & 0 & 0.2 & 4.46 & 0.87 & 0.12 \\
\hline 3) the hilt of the sword ${ }^{(*)}$ & 61.36 & 33.35 & 0 & 0 & 0.16 & 0 & 0.05 & 0.09 \\
\hline 4) the top of the cross on the hilt ${ }^{(* *)}$ & 44.59 & 3.55 & 1.77 & 15.65 & 24.79 & 0.62 & 8.53 & 0.22 \\
\hline 5) the right side of the cross ${ }^{(* *)}$ & 35.62 & 2.9 & 2.15 & 31.13 & 26.52 & 0.63 & 0.26 & 0.45 \\
\hline 6) Bulk mode ${ }^{(* *)}$ & 41.56 & 3.23 & 1.56 & 21.18 & 28.42 & 0.43 & 0.23 & 0.11 \\
\hline 7) the left side of the cross ${ }^{(* *)}$ & 45.41 & 3.67 & 1.84 & 18.92 & 27.87 & 0.62 & 0.51 & 0.15 \\
\hline 8) the sword body ${ }^{(* * *)}$ & 0.31 & 0.01 & 0 & 0.01 & 0.11 & 0 & 99.39 & 0 \\
\hline 9) the middle of the sword ${ }^{(* * *)}$ & 0.48 & 0.06 & 0 & 0.01 & 0.1 & 0.01 & 98.72 & 0 \\
\hline
\end{tabular}

Table (1-b) XRF elemental composition in the second face of the gilded sword.

\begin{tabular}{llllllllll}
\hline \multicolumn{1}{c}{ Sword samples } & \multicolumn{8}{c}{ Elements (\%) } \\
\cline { 2 - 10 } & $\boldsymbol{C u}$ & $\boldsymbol{Z n}$ & $\boldsymbol{S n}$ & $\boldsymbol{A u}$ & $\boldsymbol{A g}$ & $\boldsymbol{P b}$ & $\boldsymbol{F e}$ & $\boldsymbol{S b}$ \\
10) the hilt of the sword $(*)$ & 61.14 & 33.5 & 0 & 0 & 0.14 & 0 & 0.03 & 0.09 \\
11) the top of the hilt $(*)$ & 60.78 & 4.50 & 2.66 & 0 & 28.23 & 2.89 & 0.3 & 0.23 \\
12) the top of the cross on the hilt $(* *)$ & 39.37 & 3.3 & 2.19 & 21.16 & 25.54 & 0.66 & 7.09 & 0.41 \\
13) the right side of the cross $(* *)$ & 40.16 & 3.23 & 1.99 & 25.83 & 27.50 & 0.68 & 0.2 & 0.15 \\
14) the left side of the cross $(* *)$ & 41.08 & 3.22 & 2.15 & 24.34 & 27.79 & 0.71 & 0.24 & 0.25 \\
15) the Sword body $(* *)$ & 0.26 & 0.02 & 0 & 0.01 & 0.11 & 0.03 & 99.34 & 0 \\
16) the middle of the sword $(* * *)$ & 0.29 & 0.02 & 0 & 0.02 & 0.12 & 0 & 99.29 & 0 \\
\hline
\end{tabular}

(*) Copper alloy

(**) Gold alloy

(***) Iron alloy 


\section{Discussion}

According to the analytical methods, it could be said that the gilded layer has many defects which sometimes occurred as a result of impurities in the alloy or metal overheating that induce brittleness, and these cracks in the gilded layer can indicate selective corrosion of the base metal. The gilded layer was most probably made of gold foils or gold leaves and not of sheets, whereas gold sheet is a thick layer of gold, since gold foils have an intermediate thickness of more than about $10 \mu \mathrm{m}$, while gold leaves have a thickness of less than $10 \mu \mathrm{m}$; and possibly low as $0.1 \mu \mathrm{m}[10,13]$. The ternary alloy of gold, silver and copper are less ductile and quality of the foil decreases. A gold leaf can reach a thickness of less than $1 \mu \mathrm{m}$ [15]. The cohesion between the gilding and the base alloy was damaged, suggesting either the use of a quite durable adhesive or that some diffusion among the metals has taken place. Any mechanical attachment would most likely lead to the formation of a strong corrosion among the two metals, in the same way as the use of a less durable organic adhesive that would easily decay under burial $[16,20]$. The brass alloy (copper and zinc alloy) commonly has $30 \%$ Zinc. Most historians believed that using zinc mixed with copper started at the beginning of $500 \mathrm{BC}$. The Romans were the first to use that mixture on a large scale by melting zinc with copper and adding other elements to the alloy such as tin at a percentage ranging from $0.1 \%-0.2 \%$. They believed that this would improve the characteristics of the alloy and its resistance to corrosion, and adding lead to the alloy would also improve its flexib- ility and ductility and thus facilitating the process of operation and formation. However, it is clear that the solubility of lead in copper is limited. The contact between silver and copper in the hilt of the sword enhanced the corrosion phenomenon whose main agent is the chloride anion coming from the surrounding environment, this induces the formation of silver and $\mathrm{Cu}$ (I) chlorides that could give rise to the copper cyclic reaction that continues to corrode copper when exposed to oxygen and humidity [21-23]. $\mathrm{X}$-ray fluorescence analysis reveals the sword's body made of iron alloy. Microscopic examinations with optical and stereo microscopes, fig. (3) showed cracks and pits, and also nodes of various shapes: moles, flat bulbs etc., and also monochrome surface spots of various sizes formed probably due to mechanical damage of the sword and internal defects in the alloy. Deterioration of iron occurs when two (or more) dissimilar metals are brought into contact in the presence of moisture. When a galvanic couple forms, one of the metals becomes the anode and corrodes faster than it would on its own, while the other metal becomes the cathode and corrodes slower than it would alone. The driving force for this type of deterioration is the potential difference between the different metals. In a galvanic couple, the less noble metal will become the anode of the corrosion cell while the more noble metal will act as the cathode. Galvanic deterioration is one of the more common and destruction forms of iron corrosion [24-27]. This deterioration causes distribution of pitting corrosion on the surface of the sword's body.

\section{Conclusion}

The examination and analytical methods used to investigate the gilded sword dated back to the Ottoman period $15^{\text {th }}-17^{\text {th }}$ century $A D$ revealed significant conclusion relating to the corrosion process which continuous during exhibited in the museum, the chemical composition of the sword alloy, the condition of the gilding layer and to explore the technique utilized. Examination under optical and stereo microscopes showed the surface had many cracks and pits with a brittle appearance, and some pits have corrosion products. Pitting considered more dangerous than uniform deterioration, it is more difficult to detect. A narrow pit can lead to the failure of an entire structure by creating reactive electrochemical areas. 
The portable XRF analyses were provided with information about the chemical composition of alloys. Three different alloys are detected on the gilded sword: 1) the hilt of the sword made from brass (an alloy of copper and zinc), 2) the cross which was upon the hilt made from gold or electrum (an alloy of gold, silver and copper with small amounts of zinc, tin and lead), and 3) the blade of the sword made from iron alloy. These different contents played a serious role in deterioration and degradation processes. So the gilding layers which most probably made of gold foil or gold leaves was un-continuous and tears and the iron blade had many pits. In addition, the presence of a corrosive environment allows for more rapid cracks and pits growth. The previous study could help to preserve and protect the gilded sword in the Islamic Art museum without causing further damages by apply safe technique as mechanical cleaning. It enables the conservator to make maximum control over the cleaning processes. Mechanical cleaning could apply to remove deposits by soft brushes, glass bristle brushes, and blunt chisel. Finally, the sword must isolate by $4 \%$ paraloid B72 in acetone.

\section{References}

[1] http://www.metmueum.org/toah/hd/ isaa/hd_isaa.htm (13-10-2004).

[2] Loanid, E., Loanid, A., Rusu, D. \& Dorofti, F., (2011). Surface investingation of some medieval silver coins cleaned in high-frequency cold plasma, J. of Cultural Heritage, Vol. 12, pp: 220-226.

[3] Killick, D., (2004). Social constructionist approaches to the study of technology, World Archaeology, Vol. 36 (4), pp: 571-578.

[4] Siano, S., Bartoli, L.,Santisteban, J., Kockelmann, W., Daymond, M., Miccio, M., \& De Marinis, G., (2006). Nondestructive investigation of bronze artifacts from the Marches National Museum of Archaeology using neutron diffraction, Archaeometry, Vol. 48, pp: 77 -96.

[5] Conrad, S. \& Rehren, Th., (1995). The silver mummy mask from Hildesheim: Restoration or conservation, in: SCA (eds.) $I^{\text {st }}$ Int. Conf. on Ancient Egyptian Mining and Metallurgy and Conservation of Metallic Artifacts, Cairo, Egypt, pp: $235-248$

[6] Sandu, I.C.A., Afonoso, L., Murta, E. \& Helena, M., (2010). Gilding techniques in religious art between east and west, $14^{\text {th }}-18^{\text {th }}$ centuries, IJCS, Vol. 1 (1), pp: 47-62.

[7] Agoston, G. \& Masters, B., (2009). Encyclopedia of the Ottoman Empire, facts on file books Inc., New York.

[8] Danisman, H., El-Gomati, M., Abattouy, M. \& Ayduz, S., (2007). Ottoman mining and metal working

in the Balkans: Technology of south east Europe $\left(15^{\text {th }}-17^{\text {th }}\right)$. FSTC limited, UK.

[9] Alexander, D., (2001). Swords and sabers during early Islamic period, Gladius, Vol. 21, pp: 193-220.

[10] Darque-Ceretti, E., Aucouturier, M., Felder, E., Burr, A., Robcis, D. \& Thoma, C., (2015). New leaf gilding alloys: Physic-chemistry, color, mechanical behavior, IJCS, Vol. 6 (Special Issue), pp: 531-540.

[11] Sparavigna, A., (2016). Depletion gilding: An ancient method for surface enrichment of gold alloys, Mechanics, Materials Science and Engineering, Vol. 2 (1), pp: 99-105

[12] Mircea, O., Sandu, I., Vasilache, V., and Sandu, A., (2013). Applications of optical microscopy and energydispersive $\mathrm{x}$-ray spectroscopy in the study of a pendant from the II NDIIIRD century AC, IJCS, Vol. 4 (Special Issue), pp: 701-709.

[13] Ghoniem, M., (2015). An Egyptian partially gilded bronze group statue: Examination and analysis, Archaeometry, Vol. 57, pp: 130 -146.

[14] Vasilache, V., Sandu, I., Mircea, O., and Sandu, V., (2013). Study on the conservation state of gilded silver coin from XVTH century, discovered in Romania, IJCS, Vol. 4 (Special Issue), pp: 710-714.

[15] Gulotta, D., Goidanich, S., Bertoldi, M., Bortolotto, S. \& Toniolo, L., (2012). Gildings and false gilding of the Baroque age: characterization 
and conservation problems, Archaeometry, Vol. 54, pp: 940-954.

[16] Figueiredo, E., Rui, J.C., Silva, M., Fatima, A., Joao, C. \& Martinez, S., (2010). Identification of ancient gilding technology and late Bronze age metallurgy by EDXRF, Micro-EDXRF, SEM-EDS and metallography, Microchim Acta, Vol. 168, pp: 283-291.

[17] Tantrakam, K., Kato, N. \& Nakal, I., (2012). The application of portable $\mathrm{x}$-ray fluorescence spectrometer analysis of glass vessel fragment from Southern Thailand, Archaeometry, Vol. 54, pp: 508-527.

[18] Koenig, C., Castaneda, A., Boyd, C., Rowe, M. \& Steelman, K., (2013). Portable X-Ray fluorescence spectroscopy of pictographs: A case study from the lower Pecos Canyonlands, Texas, Archaeometry, Vol. 56, pp: 168-186.

[19] Frame, L., Freestone, I., Zhang, S. \& Nicholas, M., (2013). The effect of corrosion and conservation treatment on non-destructive neutron diffraction analysis of archaeological copper alloys: Preliminary results, Archaeometry, Vol.55, pp: 68-80.

[20] Angelini, E., Grassini, S., De Caro, T. \& Ingo, G., (2007). Survey of the Italian archaeological precious metal collections: Characterization of the patina and study of the degradation phenomena, in: Argyropoulos, V., Hein, A. \& Abdel Harith, M. (eds.) Strategies for Saving Our Cultural Heritage, Cairo, Egypt, pp: 184-188.
[21] Megahed, M., (2014). Assessment of some Ag-based coins from Ayyubid period, Yemen, corrosion and methods of treatment, IJCS, Vol. 5 (3), pp: 309-320.

[22] Sandu, I.G., Mircea, O., Vasilache, V. \& Sandu, I., (2012). Influence of archaeological environment factors in alternation processes of copper alloy artifacts, Microscopy Research and Technique, Vol. 75, pp: 16461652.

[23] Oudbashi, O. \& Shekofteh, A., (2015). Chemical and microstructural analysis of some Achaemenian silver alloy artifacts from Hamedan, Western Iran, Periodico dI Mineralogia, Vol. 84 (3A), pp: 419-434.

[24] Hamilton, D., (1999). Methods of conserving archaeological material from underwater sites, Nautical Archaeology Program, Department of Anthropology, Texas A\&M Univ., USA.

[25] Ehrlich, H., (1997). Microbes and metals, Microbial Biotechnol, Vol. 48, pp: 687-692.

[26] Jegdic, B., Radovanovic, S., Ristic, S. \& Alil, A., (2012). Corrosion stability of corrosion products on an archaeological iron artifact, IJCS, Vol. 3 (4), pp: 241-248.

[27] Kostoglou, M. \& Navasaitis, J., (2006). Cast iron in ancient Greece: myth or fact, $M A A$, Vol. 6 (2), pp: 53-56. 